\title{
Assessment of water resources in some drainage basins, northwestern coast, Egypt
}

\author{
Mohamed Yousif • El Sayed El Abd • \\ Ahmed Baraka
}

Received: 6 July 2012/ Accepted: 28 February 2013/Published online: 14 March 2013

(c) The Author(s) 2013. This article is published with open access at Springerlink.com

\begin{abstract}
The main objective of this research paper is to monitor the current situation of water resources in some of the drainage basins in the northwestern coast of Egypt and reach to a plan for the development of these resources. The selected basins were chosen for the present study according to their special conditions, where they have a shortage of water for human and agriculture proposes. However, the area of study has a population growth and agricultural activities, which require necessary development of groundwater. The study area has two aquifers: Pleistocene, and Middle Miocene aquifers. The recharge to these aquifers comes either from the direct infiltration of the rainfall, and/or from the surface runoff. The groundwater in the area of study is evaluated for drinking, domestic, livestock and agricultural purposes. The present study reaches out for some recommendations to develop the surface and groundwater in the study area.
\end{abstract}

Keywords Egypt - Surface water - Groundwater · Geomorphology · Geology · Drainage basin

\section{Introduction}

The sustainable development aims at maintaining the equilibrium between the human needs and economic developments within the parameters of environmental conservation through efficient use of natural resources to ensure trade-off between desired productions-consumption levels. The development of natural resources is based

M. Yousif $(\bowtie)$ · E. S. E. Abd · A. Baraka

Geology Department, Desert Research Center, P.O.B. 11753,

El Matariya, Cairo, Egypt

e-mail: yousif_mohamed80@daad-alumni.de on maintaining the fragile ecosystem balance between the productivity functions and conservation practices through monitoring and identification of problem areas. The planning of the study area needs a concerted effort to arrive at a decision for any development activity incorporating all limiting and delimiting factors, their correlation and interaction. The basic need in any planning exercise is to have a well-defined database. In this regard, the assessment of water resources requires the monitoring of the current situation and reach to a plan for the future development. Egypt is an arid land with virtually $96 \%$ of its territory uninhabited parts. The Nile Valley and the Delta areas represent $4 \%$ of Egyptian land, but the majority of people inhabit this area. The expectation indicates that the size of Egyptian population will duplicate in the next 25 years. A growing human population is making demands on the coastal zone for living space, leisure and recreation, and a host of other purposes. The surface water in the coastal area is very limited in magnitude as it originates from the rainfall of the winter season (Sewidan 1978; El Bastawesy et al. 2008). Physiographically, the northwestern Mediterranean coastal zone can be differentiated into two main provinces. These are the elevated tableland in the south, and the coastal zone to the north. A great number of northward-flowing drainage lines (Wadis) dissect the elevated tableland. Runoff is possible after rather heavy rains, and a considerable amount of water may percolate to deeper soil layers. In the present study, four drainage basins were chosen to carry out this research. The main objectives of the present study are the assessment of water resources in these basins as case studies for the development of surface and groundwater in the northwestern coast of Egypt. In addition, to monitor the current situation and reach to recommendations include the best sites for surface water harvesting and groundwater exploration. This work 
can be considered as a part of a research project which carried out by Desert Research Center to provide the needs of water for the people in the northwestern coast of Egypt. In this context, the current research is an integration between studies for water resources development; these studies include geomorphology, geology and hydrogeology. The study will deal with current situation of the surface and groundwater to assess the potentialities of the study area, then it will progress to put a plan for the water resources development. The northwestern coast of Egypt is a subject for many studies, which includes different disciplines. The literature has a good number of regional and local studies about geology, geomorphology and hydrogeology investigations. Regional information on the hydrogeological conditions of the northwestern coastal zone of Egypt can be found in several publications and theses such as El Shamy (1968), Hammad (1966, 1972), Misak (1974), El Shazly et al. (1975), Ezzat (1976), Hilmy et al. (1978), Sewidan (1978), Guindy (1989) and El Maghraby (1997). Also, some reports were prepared such as FAO (1970), Mudallal (1990), El-Raey (1998), NARSS (2005), and World Bank report (2005). The previous literature concluded that the northwestern coast receives amounts of annual rainfall where distributed in the form of surface runoff, and/or infiltrate to recharge the groundwater, (Raslan 1995; El-Raey; 1998; Klaric et al. 1999; El-Sharabi E 2000). These studies were dealt regionally with the whole coast or some zones from it. Consequently, the present research is focusing on four basins from different sites along the coast, to assess and monitor their water resources in detailed discussion.

\section{Area of study}

The study area is bounded by longitudes $26^{\circ} 30^{\prime}$ and $28^{\circ} \mathrm{E}$ and latitudes $31^{\circ}$ and $31^{\circ} 30^{\prime} \mathrm{N}$ (Fig. 1). Four drainage basins were chosen for the present study; these basins from west to east are Wadi Shebity, Wadi Habis, Wadi Hashim, and Wadi Kheriga. The selected basins have a special interest due to its agricultural activities, which need more water resources to be sustainable and not temporary. However, the studied area is characterized by gentle dipping (to the north) bedrock of carbonate lithology. The northern part of the studied area is characterized by the occurrence of a series of elongated ridges oriented parallel to the coast and alternating with shallow elongated depressions.

\section{Climate}

The climate of the study area is characterized by a rainy unstable winter and a stable warm and dry summer. The other two seasons are also characterized by unstable climatic conditions, e.g., some storms during spring, and occasional sudden heavy rainfall during autumn. The area of study is characterized by milder climatic conditions, compared to the rest of Egypt. The Mediterranean coastal zone of Egypt receives noticeable amounts of rainfall, especially in winter. The rainy months are October, November, December, January, and February. In summer, no rain is recorded, while in autumn, occasional heavy rain may occur. Since the year 1998, the Desert Research Center has been installing meteorological weather stations along the northwestern coast to measure the amount of rainfall. The average annual precipitation in the period from 1998 to 2006 was $103.1 \mathrm{~mm}$ in El Negela station, $113 \mathrm{~mm}$ in Matrouh Station, and $101.5 \mathrm{~mm}$ in Ras El Hekma Station (Table 1). Precipitation is considered as the main source of recharge of groundwater aquifers in the northwestern Mediterranean coastal zone and affects greatly the amount of water stored in such aquifers.

\section{Geomorphology}

The study area occupies a portion of the northwester coast of Egypt, which is characterized by sub-arid climatic conditions. The natures of the climate, together with existing geologic conditions have an effect on the present landforms of this area. On the regional level, four main geomorphologic units are distinguished: the tableland, Piedmont plain, the coastal plain, and the drainage basins (Figs. 2, 3). These units are oriented in a nearly E-W direction i.e., nearly parallel to the present Mediterranean shore. On the other hand, in some places, the local geological structure allows the land surface to extend into the sea with NE-SW trend in the form of headland. Based on field investigations, topographic maps, and digital elevation model, the local geomorphological aspects will be discussed from south to north in the following:

\section{Tableland}

The tableland constitutes a prominent geomorphologic unit bounding the coastal and Piedmont plains from the south. It occupies the northern extremity of the great Marmarican Homoclinal plateau and extends to the Qattara Depression. The tableland occupies areas of $2.2 \mathrm{~km}^{2}$ in Wadi Shebity, $1 \mathrm{~km}^{2}$ in Wadi Habis, $0.6 \mathrm{~km}^{2}$ in Wadi Hashim, and $1.9 \mathrm{~km}^{2}$ in Wadi Kheriga and its surface has slopes of 11.62, 24.29, 33.67 and $10.63 \mathrm{~m} / \mathrm{km}$, respectively. The tableland is composed mainly of fissured and jointed limestone whose top portion is highly weathered and is developed into a hard pink crust. The tableland area displays complex geomorphological features; at some localities, the northern edge of the tableland area is characterized by the occurrence of a welldeveloped escarpment facing north and separating the tableland from the northern coastal plain (Fig. 2). On the 
Fig. 1 Location map of the study area

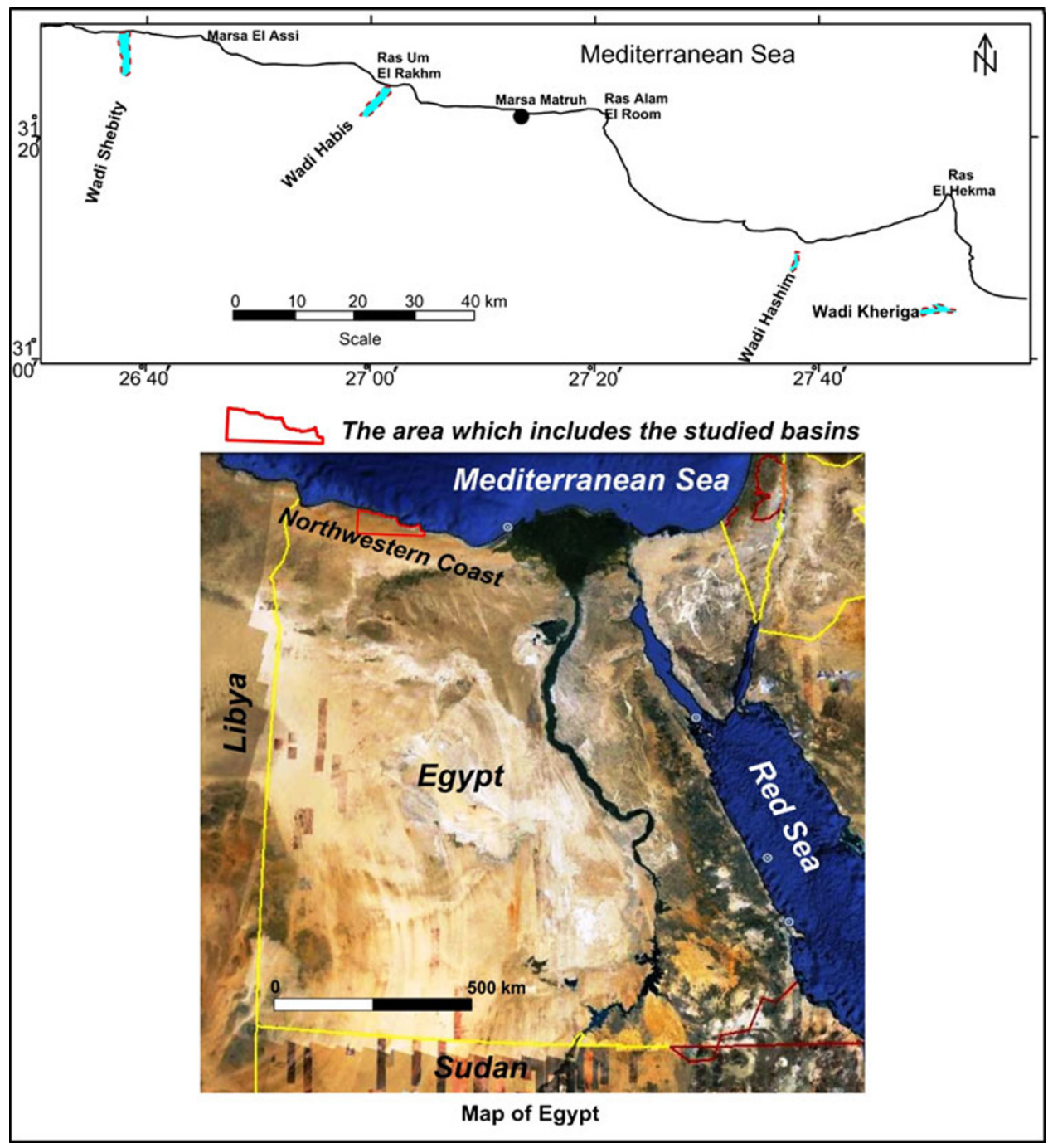

other hand, the northern portion of the tableland area is dissected by a number of short and deep consequent valleys acting during rainy seasons as active drainage lines. The bottom of the drainage lines dissecting the tableland is occupied by thick alluvial deposits composed of gravel, cobbles intermixed with sand, silt and finer material. The tableland represents the main watershed area in the northwestern Mediterranean coastal zone. The northward slope of the surface and the development of hard crust on the top of the weathered surface favor the surface water runoff to be directed either to the depressions of the Piedmont plain where it forms small ephemeral lakes and in some localities, the drainage water flows directly to the Mediterranean Sea.

\section{The Piedmont plain}

The Piedmont plain represents an extended sloped surface separating the tableland to the south from the coastal plain to the north (Fig. 2). It is well developed where the tableland escarpments are well pronounced. It occupies an area of about $1.14 \mathrm{~km}^{2}$ in Wadi Shebity, $0.94 \mathrm{~km}^{2}$ in Wadi Habis, $0.46 \mathrm{~km}^{2}$ in Wadi Hashim, and $0.77 \mathrm{~km}^{2}$ in Wadi Kheriga. Its surface is either covered with thin layer of alluvial and sand deposits or degraded and appears as rocky surface. During the rainy season, the plain receives much of the surface runoff of both the tableland and the most inland ridge. The surface of this plain is mainly occupied by scattered, disconnected and irregularly oriented lowlying limestone ridges. The low lands surrounding these ridges are filled with a stony and pebbly calcareous soil, which appears suitable for cultivation. The Piedmont plain is occupied by subunits as, inland ridges, and depressions.

\section{The coastal plain}

The coastal plain occupies the peripheral zone parallel to the present Mediterranean shoreline. The coastal plain is characterized by the occurrence of a series of elongated 
Table 1 Monthly rainfall data from the installed Desert Research Center stations in (mm), seasons (1998-2006)

\begin{tabular}{|c|c|c|c|c|c|c|c|c|c|c|}
\hline Station & Season & October & November & December & January & February & March & April & Total & $\begin{array}{l}\text { Average } \\
(\mathrm{mm})\end{array}$ \\
\hline \multirow{8}{*}{$\begin{array}{l}\text { El Negela station (nearest station } \\
\text { to Wadi Shebity basin) }\end{array}$} & 1998-1999 & 0 & 7.8 & 68.1 & 34.3 & 21.8 & 4.2 & 0.5 & 136.7 & \multirow[t]{8}{*}{103.1} \\
\hline & 1999-2000 & 1.2 & 16.6 & 3.1 & 107.2 & 35.1 & 7.4 & 2.1 & 172.7 & \\
\hline & 2000-2001 & 3.9 & 48 & 49.5 & 9 & 11.2 & 0.8 & 0 & 122.4 & \\
\hline & 2001-2002 & 7 & 0 & 24.3 & 34.3 & 0.9 & 0 & 0 & 66.5 & \\
\hline & 2002-2003 & 12 & 2.6 & 18.5 & 24 & 22 & 26.9 & 0 & 106 & \\
\hline & 2003-2004 & 0 & 0.7 & 18.1 & 47 & 19.5 & 0 & 0 & 85.3 & \\
\hline & 2004-2005 & 7.6 & 35.8 & 0 & 1.8 & 0 & 0 & 0 & 45.2 & \\
\hline & 2005-2006 & 3 & 15 & 30 & 40 & 2 & 0 & 0 & 90 & \\
\hline \multirow{8}{*}{$\begin{array}{l}\text { Matrouh station (nearest station } \\
\text { to Wadi Habis basin) }\end{array}$} & 1998-1999 & 0 & 19.4 & 52.2 & 17.1 & 18.6 & 0.4 & 0 & 107.7 & \multirow[t]{8}{*}{113} \\
\hline & 1999-2000 & 0 & 19 & 3.8 & 103 & 16.3 & 4.7 & 1.6 & 148.4 & \\
\hline & 2000-2001 & 12.4 & 28.7 & 46.6 & 17.5 & 18.9 & 0.1 & 0 & 124.2 & \\
\hline & 2001-2002 & 14.4 & 8.4 & 26.6 & 51.3 & 8.3 & 0 & 0 & 109 & \\
\hline & 2002-2003 & 6.9 & 1.7 & 30.4 & 15.4 & 41.3 & 31.9 & 0 & 127.6 & \\
\hline & 2003-2004 & 0 & 10.7 & 33.8 & 45.5 & 22 & 0 & 0 & 112 & \\
\hline & 2004-2005 & 5.1 & 12.7 & 9.7 & 34.29 & 12.44 & 0 & 0 & 74.23 & \\
\hline & 2005-2006 & 0 & 29 & 20 & 30 & 15 & 8 & 0 & 102 & \\
\hline \multirow{8}{*}{$\begin{array}{l}\text { Ras El Hekma station (nearest station } \\
\text { to Wadi Hashim and Wadi Kheriga } \\
\text { basins) }\end{array}$} & 1998-1999 & 0 & 5.2 & 51.8 & 20.55 & 20 & 0.4 & 0 & 97.95 & \multirow[t]{8}{*}{101.5} \\
\hline & 1999-2000 & 17.7 & 6.8 & 1.5 & 93.92 & 7 & 12.4 & 2 & 141.32 & \\
\hline & 2000-2001 & 27.5 & 17.6 & 42.8 & 2.3 & 3.9 & 0 & 0 & 94.1 & \\
\hline & 2001-2002 & 0 & 0 & 7.85 & 32.7 & 2.8 & 0 & 0 & 43.35 & \\
\hline & 2002-2003 & 0 & 0 & 4.2 & 40 & 30.8 & 34 & 0 & 109 & \\
\hline & 2003-2004 & 0 & 14.5 & 36.5 & 33.5 & 6.5 & 0 & 0 & 91 & \\
\hline & 2004-2005 & 17.4 & 25.4 & 42.7 & 36.5 & 0 & 0 & 0 & 122 & \\
\hline & 2005-2006 & 7.6 & 32.9 & 34.2 & 33.5 & 5 & 0 & 0 & 113.2 & \\
\hline
\end{tabular}

Fig. 2 The main landforms in the northwestern coast (includes the four studied basins)

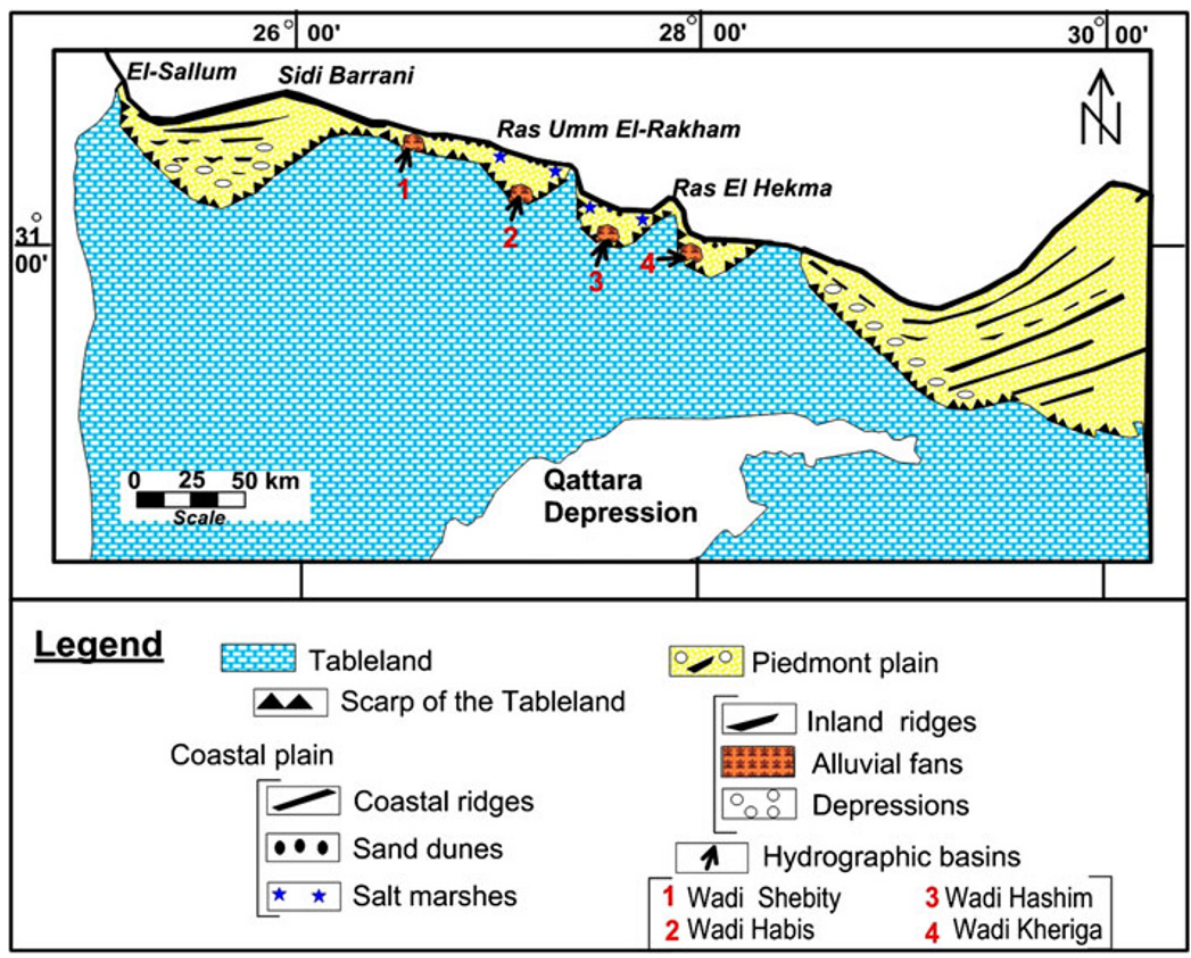




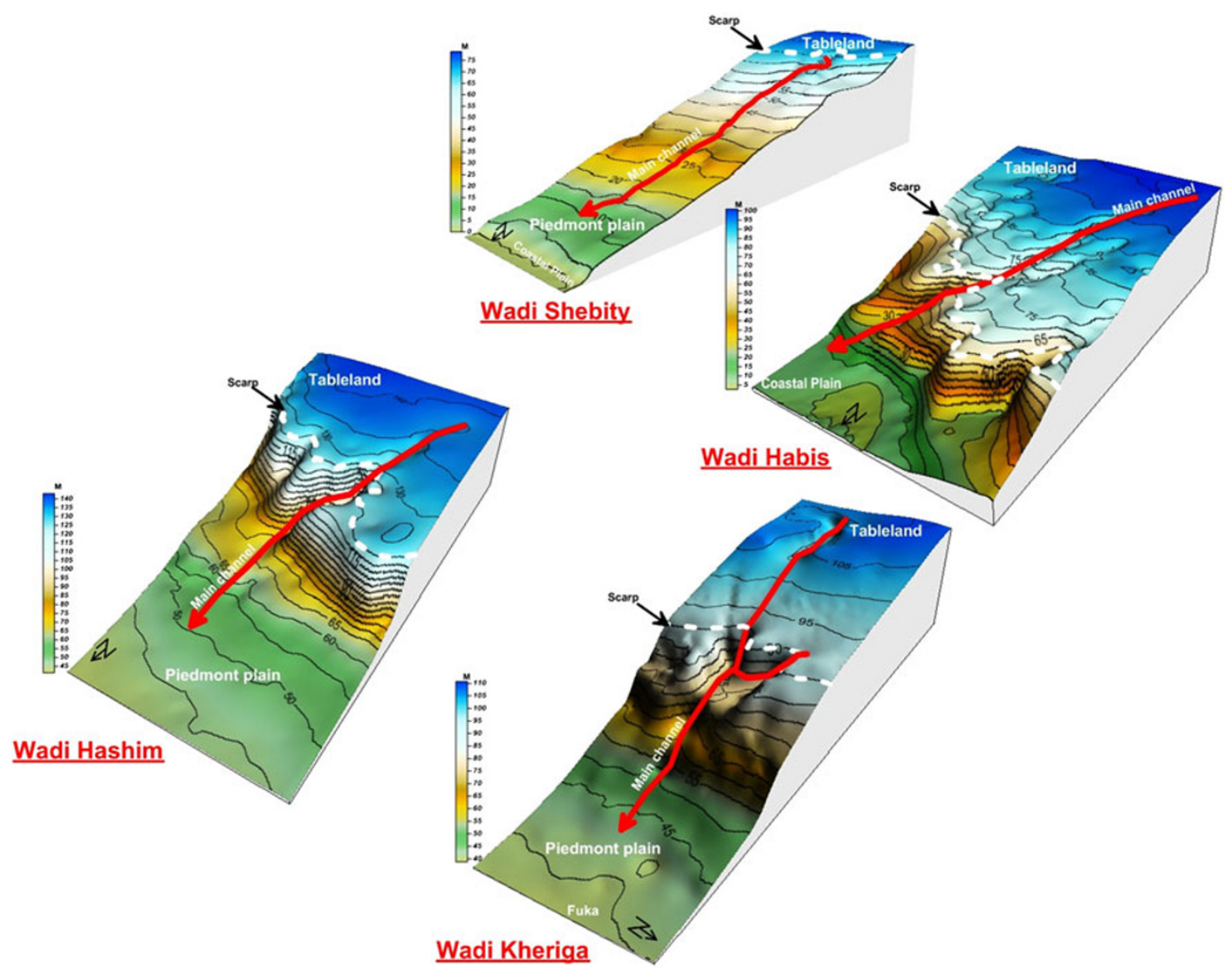

Fig. 3 Digital elevation model of the studied basins, created from topographic maps 1:25,000

ridges running parallel to the present shoreline, rising sometimes to more than $+40 \mathrm{~m}$, and attaining lower altitude towards the shoreline. These ridges represent ancient shorelines of the Mediterranean Sea and exhibiting different heights. The coastal ridges are missing or deformed at several localities due to the effect of local structures as well as due to erosion. The coastal ridges are generally composed of oolitic limestone of different degrees of hardness. They act as watershed areas during rainy season and as natural barriers for soils and water conservation. The coastal plain is occupied by subunits as, ridges, sand dunes, beaches, and slat marches.

\section{Hydrographic basins}

In the present study, four basins are subjected to the study (Fig. 3); the main channels of these basins are streaming from the tableland and drain to the sea, except Wadi Kheriga basin, which drains to Fuka basin. The general slope of each one of the studied basins were measured; however, Wadi Shebity and Wadi Kheriga have a gentle slope (14 and $12.67 \mathrm{~m} / \mathrm{km}$, respectively), while the general
Table 2 The measured parameters of the studied basins

\begin{tabular}{lllrl}
\hline Basin & $\begin{array}{l}\text { Area } \\
\left(\mathrm{km}^{2}\right)\end{array}$ & $\begin{array}{l}\text { Length } \\
(\mathrm{km})\end{array}$ & \multicolumn{1}{l}{$\begin{array}{l}\text { Perimeter } \\
(\mathrm{km})\end{array}$} & $\begin{array}{l}\text { Slope } \\
(\mathrm{m} / \mathrm{km})\end{array}$ \\
\hline Wadi Shebity & 3.91357 & 6.8665 & 13.318605 & 14 \\
Wadi Habis & 4.911523 & 5.181492 & 16.256856 & 23.87 \\
Wadi Hashim & 1.505071 & 3.353844 & 7.681933 & 29.67 \\
Wadi Kheriga & 3.356591 & 5.601633 & 16.256856 & 12.67 \\
\hline
\end{tabular}

slope increases in Wadi Habis and Wadi Hashim (23.87 and $29.67 \mathrm{~m} / \mathrm{km}$, respectively), Table (2).

Geology

\section{Stratigraphy}

Based on the field investigations, the laboratory examination of collected rock samples, the geologic map (Fig. 4; Conoco 1986), four stratigraphic sections are measured (Fig. 5). The stratigraphic units in the study area are described from older to younger as follows: 
Fig. 4 Geologic map of the study area and its surroundings, (Conoco 1986)

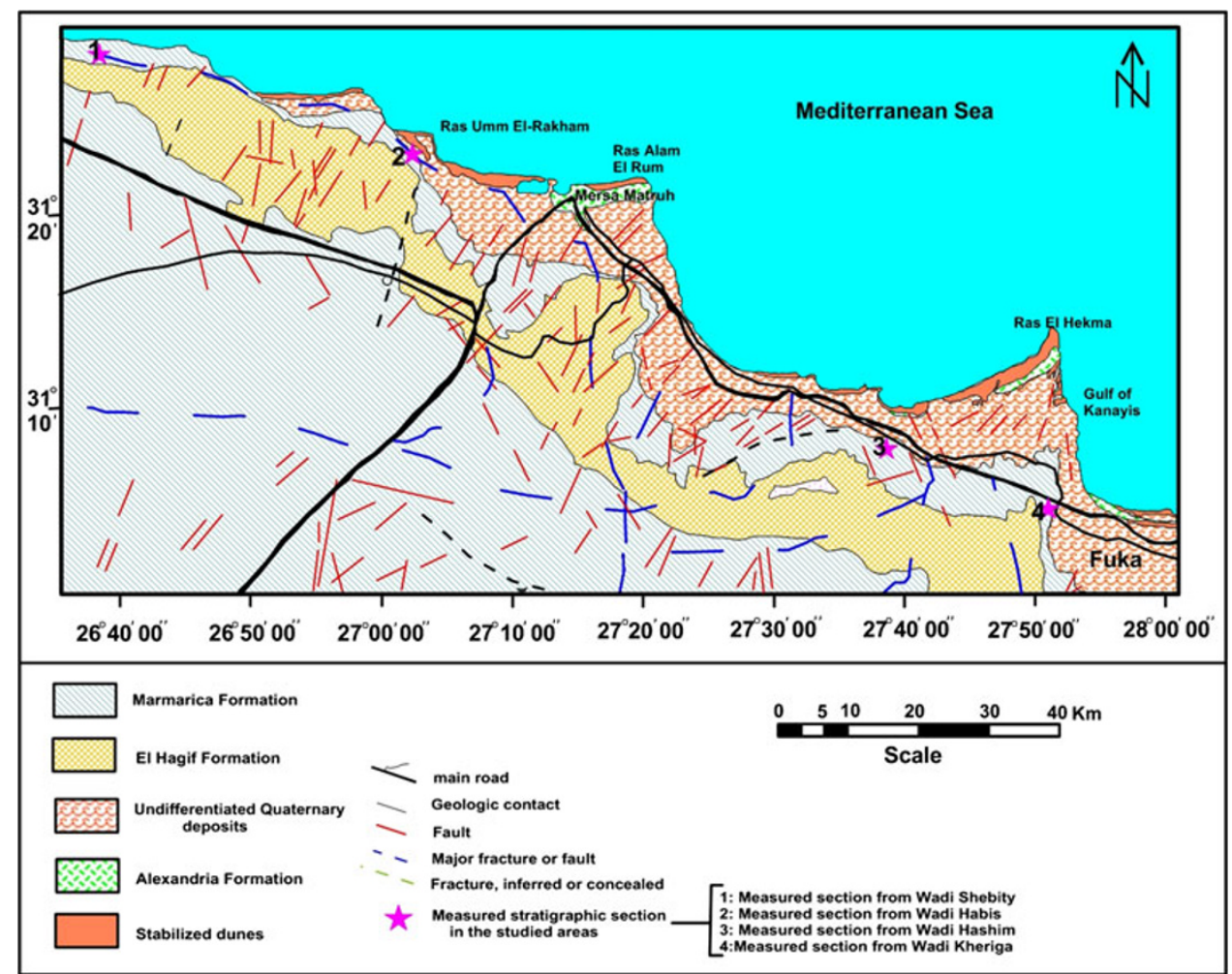

\section{Tertiary}

The Tertiary deposits are exposed mainly in the southern parts of the study area, and constitute the major part of the tableland and include the following:

Middle Miocene sediments In the study area, the Middle Miocene sediments are represented by the Marmarica limestone formation that constitutes the tableland in southern portion of the study area. This formation is built up of fissured and cavernous limestone, dolomitic limestone, and sandy limestone intercalated partly with marl interbeds. Good exposures occur on the upstream portions of Wadi Habis and Wadi Hashim. The Middle Miocene exposures are covered by a rocky crust, which is found in the top surfaces, on the slopes, or even in the drainage courses. The thicknesses of this formation varies from basin to another, where the measured thicknesses is $21 \mathrm{~m}$ in Wadi Shebity section, $47 \mathrm{~m}$ in Wadi Habis, $66 \mathrm{~m}$ in Wadi Hashim, and $42 \mathrm{~m}$ in Wadi Kheriga. This variation is due to the local structure which affected each basin and increases the thickness of Middle Miocene exposures.

\section{Quaternary}

Pleistocene sediments The Pleistocene sediments are also widely distributed in the study area and are mainly represented by oolitic limestone, which constitutes the main bulk of the Pleistocene sediments. It is almost developed in the form of ridges; these ridges are cross-bedded and composed of snow-white oolitic sand grains, which are weakly cemented and displaying yellow to grayish-yellow color on weathering. The samples collected from different localities show a range of hardness. The thickness of this formation ranges from 3 to $5 \mathrm{~m}$ in the study area.

Alluvial deposits The alluvial deposits are developed in the study area along the channels of the drainage lines in the form of Wadi terraces and Wadi fillings. These deposits are muddy deposits composed of sand, silt, and clay with abundant carbonate grains. The thickness of alluvial deposits ranges from 0.5 to $2 \mathrm{~m}$.

\section{The structural setting}

The geologic structures of the study area can be considered as a part of the main structure, which affects the northwestern coast of Egypt. The northwestern coast is a series of structurally alternating positive and negative areas trending NE-SW which affects the Mediterranean coast. The studied basins drain from the tableland, which represents a great Marmarican homocline and plunging in a NE-ward direction. Therefore, the mentioned tectonic movements lead to the occurrences of cracking and fracturing of the Middle Miocene rocks in the study area, where many fractures are recorded with different directions E-W, NE-SW, and N-S 
Fig. 5 The measured stratigraphic sections of the studied basins
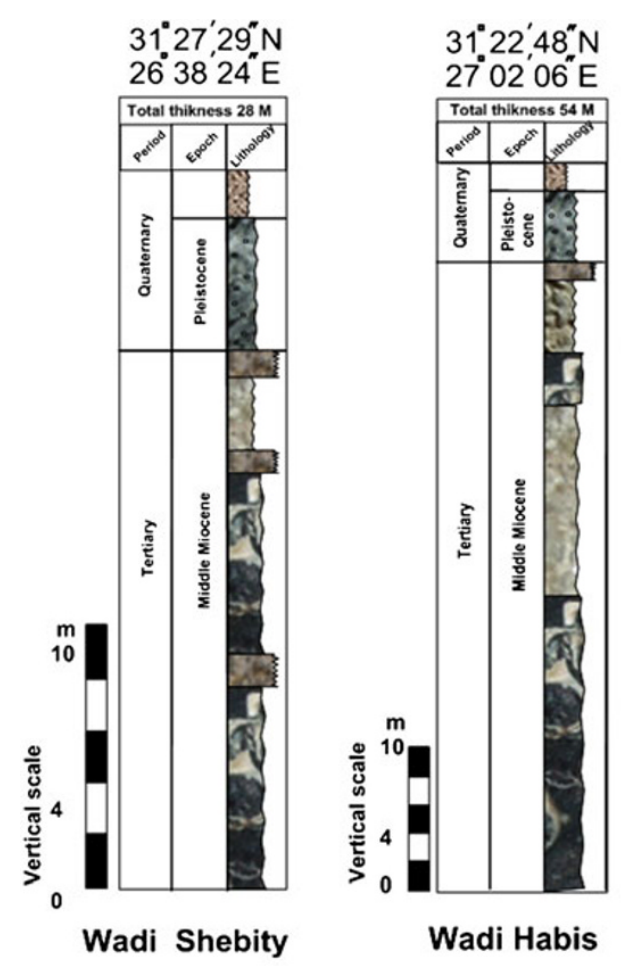

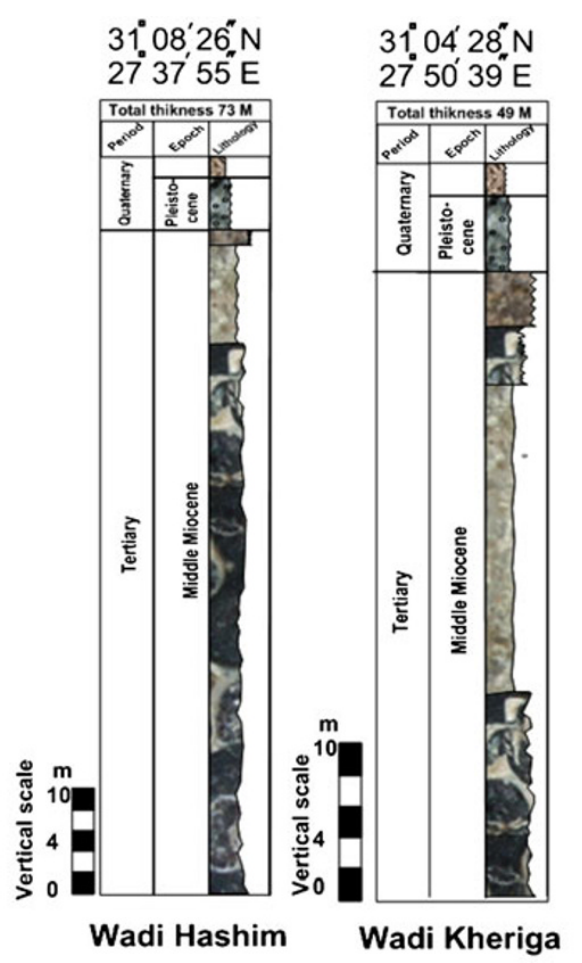

\section{Legend}
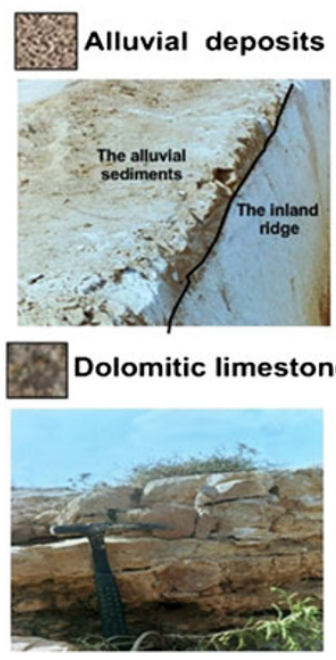

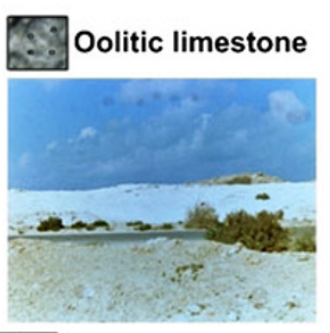

Fossiliferous limestone

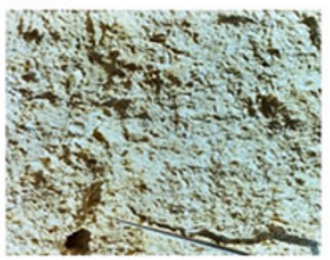

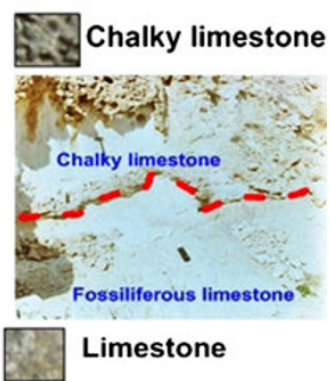

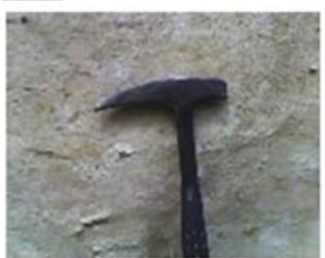

(Figs. 6 and 7). These fractures are the responsible for the occurrence of groundwater in the Middle Miocene rocks and play a main role in the recharge of this aquifer.

\section{Materials and methods}

The present work includes a group of studies that deal with geomorphology, geology, and hydrogeology. The field studies comprised geomorphological and geological mapping, surveying of water points, and collection of groundwater samples. The hydrogeologic data were also determined and measured during the field trip (such as, depth to water, total depth, water bearing formations, and hydro-geomorphologic units). The topographic maps with scales of 1:25000 and the geologic map with a scale of 1:500000 were used during field investigations and to demarcate the main landforms and structural elements with their relevancy for groundwater occurrence. During the field investigations, 60 representative samples were collected from different stratigraphic formations: these samples were described and investigated in the lab. A total of 


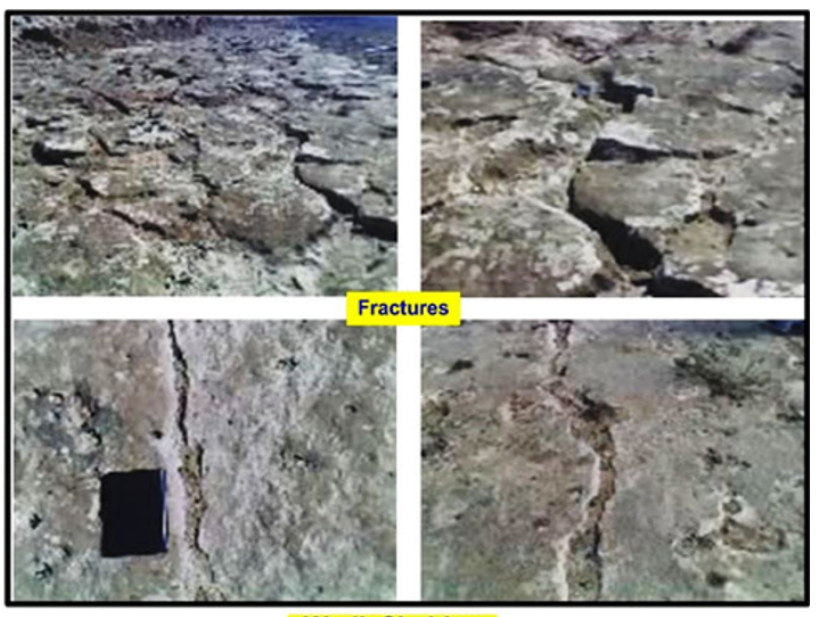

Wadi Shebity

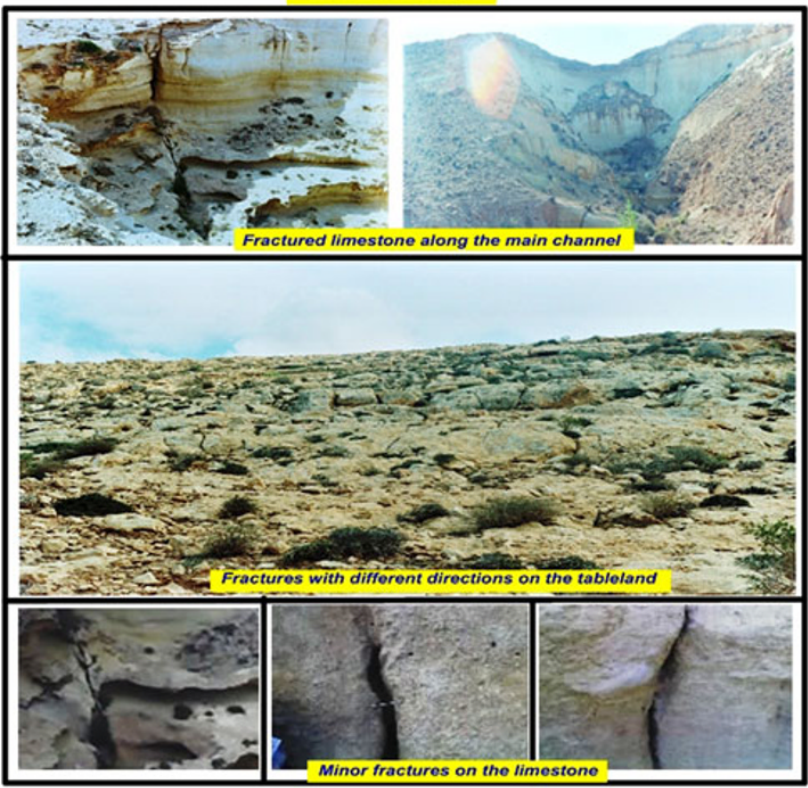

Wadi Habis

Fig. 6 Field photographs show the main structure features in Wadi Shebity and Wadi Habis basins

four groundwater samples were analyzed in the central laboratory of Desert Research Center (DRC). The recommendations for water harvesting are prepared in the present study using the topographic maps (1:25000), and field investigations.

\section{Results and discussions}

Water resources

The water resources are an essential component of all terrestrial ecosystems. Its environment is characterized by the hydrological cycle, including floods, and droughts,
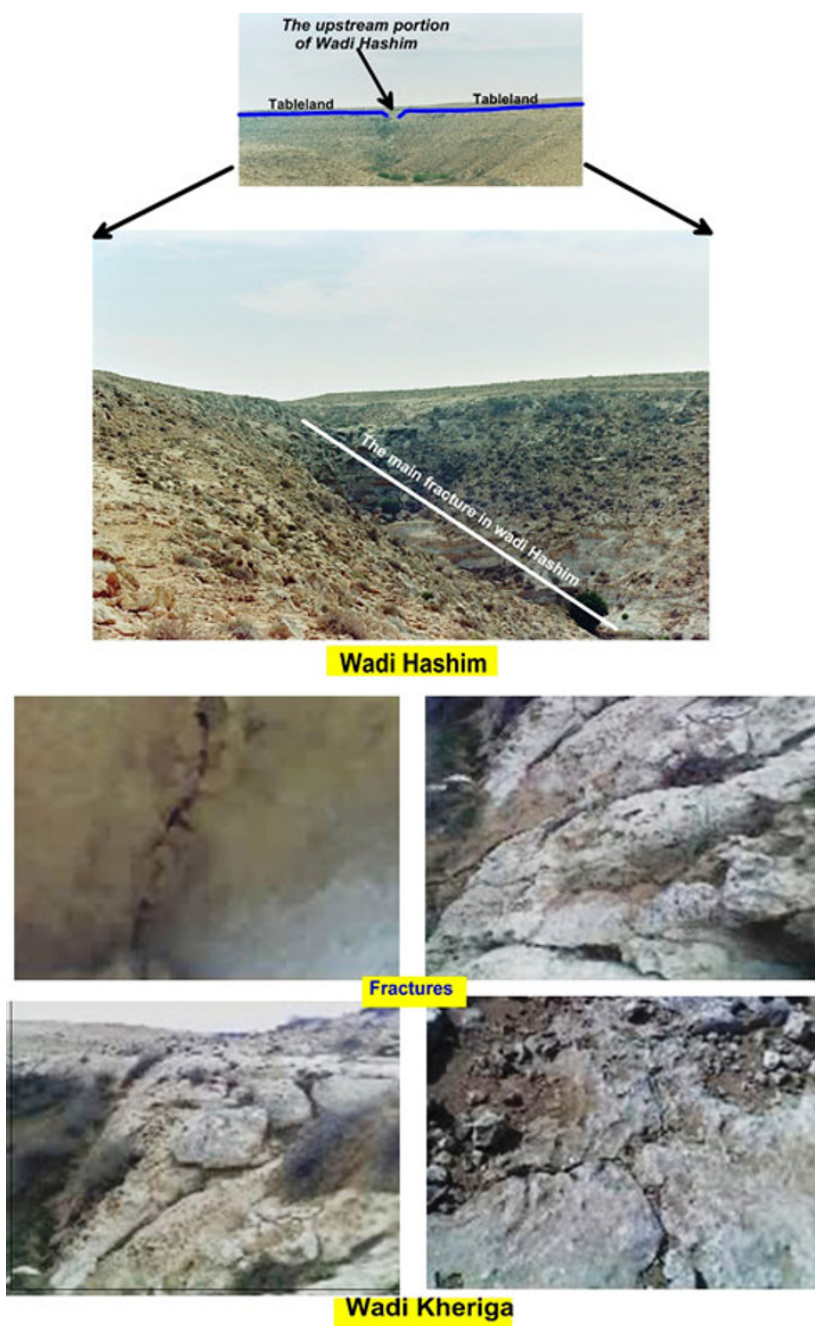

Fig. 7 Field photographs show the main structure features in Wadi Hashim and Wadi Kheriga basins

which in some regions such as marginal dry lands have become more extreme and dramatic in their consequences. Global climatic change and atmospheric pollution could also have an impact on water resources and their availability. The water resources in the study area are mainly derived from atmospheric precipitation. Usually, in the northwestern coast of Egypt, the surface runoff is collected by means of stony dams built across valleys and their tributaries, and man-made underground storage cisterns or galleries. On the other hand, groundwater is essentially discharged from wells (shallow, deep, hand-dug wells, and boreholes) and shallow open trenches. The source of groundwater recharge is through precipitation or surface water that percolates downward. The groundwater recharge of annual precipitation is dependent on climate, land use, soil type, geology and many other factors of annual precipitation that results in groundwater recharge. 

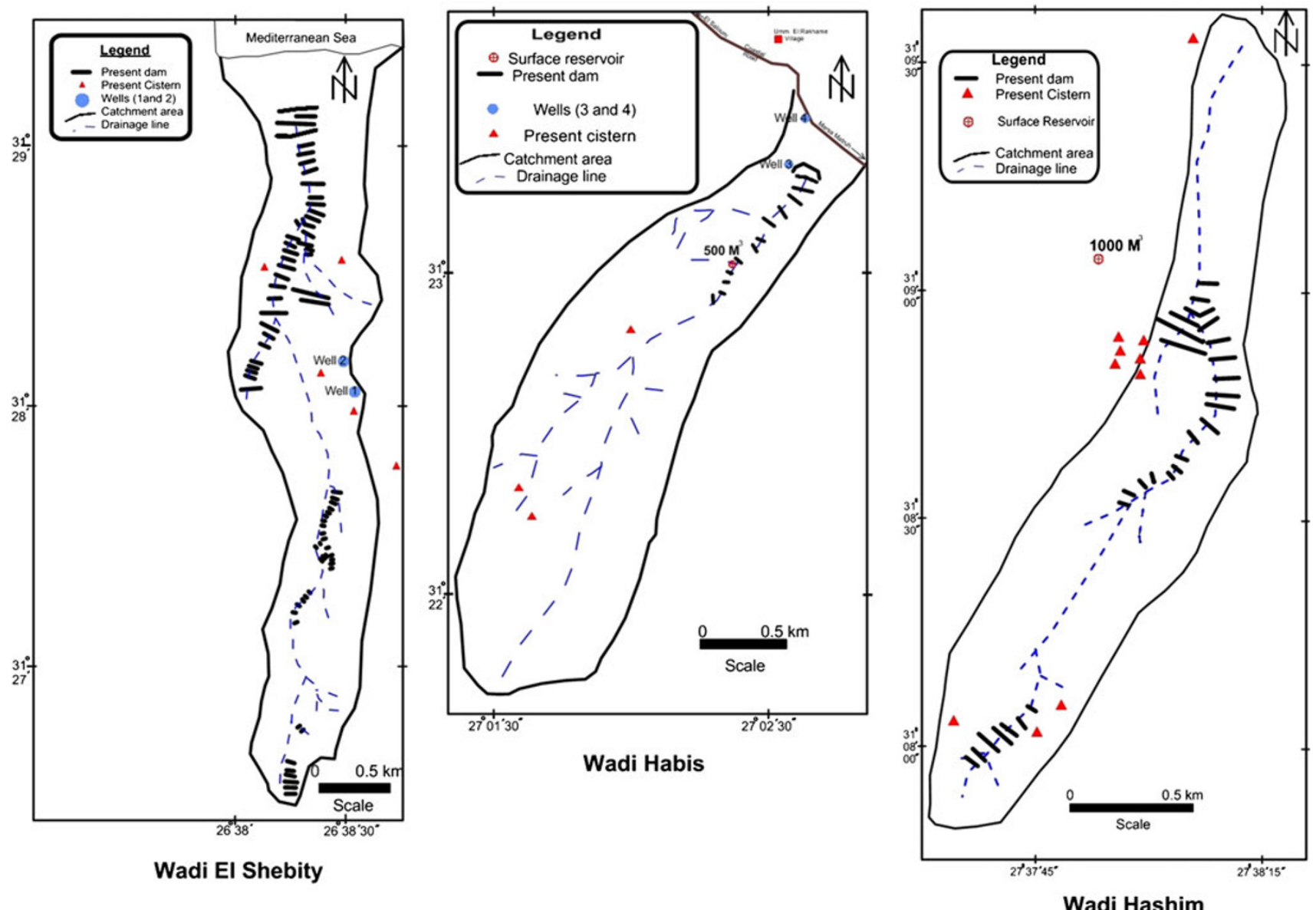

Wadi El Shebity

Wadi Hashim

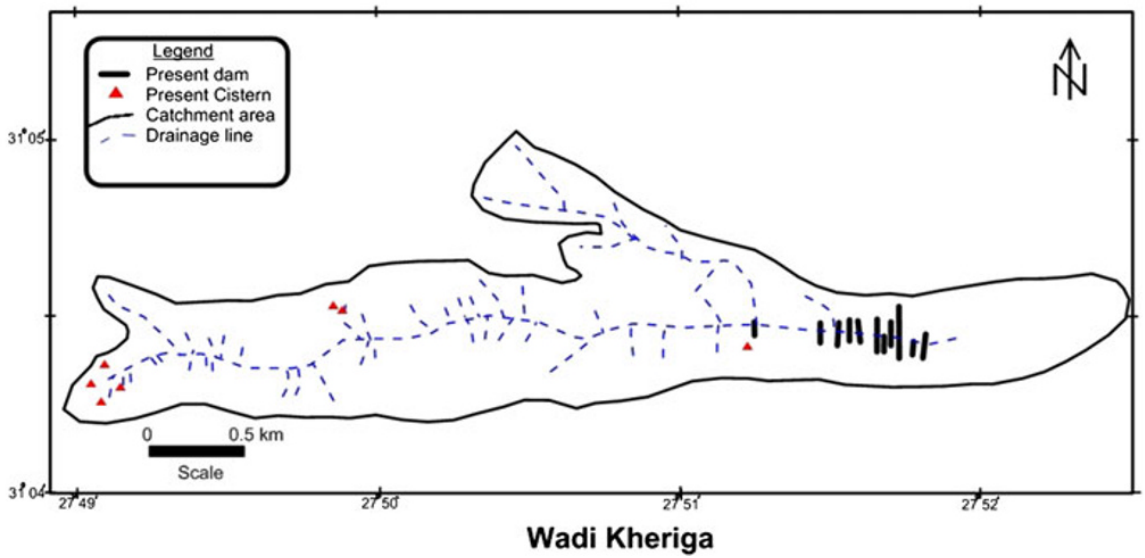

Fig. 8 Location map of the recorded activities of surface water harvesting and groundwater wells

\section{Surface water}

The study area can be differentiated into two main hydrophysiographic provinces: the watersheds, and water collector. The surface watersheds are defined by a simple process of identifying the highest elevations in land that drains to the surface water body. The southern tableland (from 100 to $140 \mathrm{~m}$ above sea level) is considered as the main watershed area of the study area, whereas the
Piedmont and coastal plains as well as the drainage network are working as water collectors. The main surface water divide is located to the studied basins where the surface runoff goes toward north. This watershed area is only used locally for grazing and barley cultivation by rainwater. The tableland is cut by the drainage basins, which drains to north. In addition, the other water divide lines are located inside the Piedmont and coastal plains where the ridges are considered as local watershed areas. 

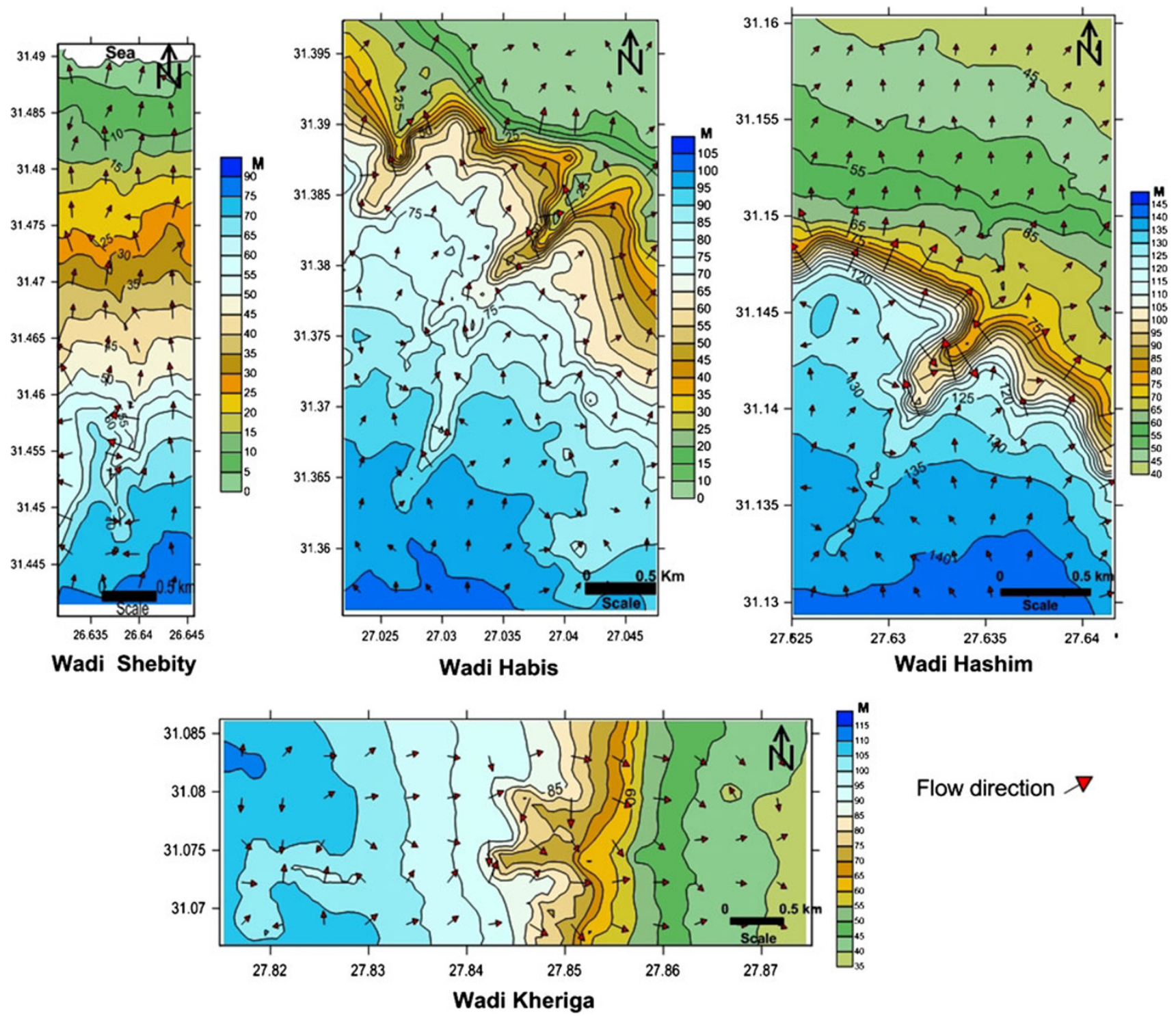

Flow direction $\boldsymbol{\nabla}$

Fig. 9 Flow direction overly contour maps of the studied basins

Rainwater flows to the north following the regional slope of the tableland surface either towards the low coastal plain and/or towards the sea. The rest of rainwater infiltrates through joints to feed the lower limestone aquifers. However, the presence of a thin hard crust accelerates the surface runoff to the north. The Piedmont and coastal plains act as collecting basins for the rainfall and runoff water from the southern tableland. The hydrographic pattern of the area was mainly developed during the Pluvial periods prevailing in the Quaternary period (Taha 1973). In the study area, a well-developed drainage pattern is absent, while the drainage patterns which are located to the south of the study area are more developed. The drainage lines dissecting the elevated tableland are structurally controlled. They are well developed in areas where lines of weakness are common (mainly South-North direction in all the studied basins, except Wadi Kheriga Basin, which is WestEast direction).

\section{Water harvesting}

Ward (1975) defined runoff as "the process which comprises the gravity movement of water in channels which may vary in size from those containing the smallest illdefined trickles to those containing the large rivers". This water represents the excess of rainfall over evapotranspiration, when allowance is made for storage on and under the ground surface. In the northwestern Mediterranean coastal zone, surface runoff is generally poor due to the low average precipitation. However, some ephemeral streams may occasionally flow through channels of dry valleys already engraved in the tableland. In the study area, some of the 


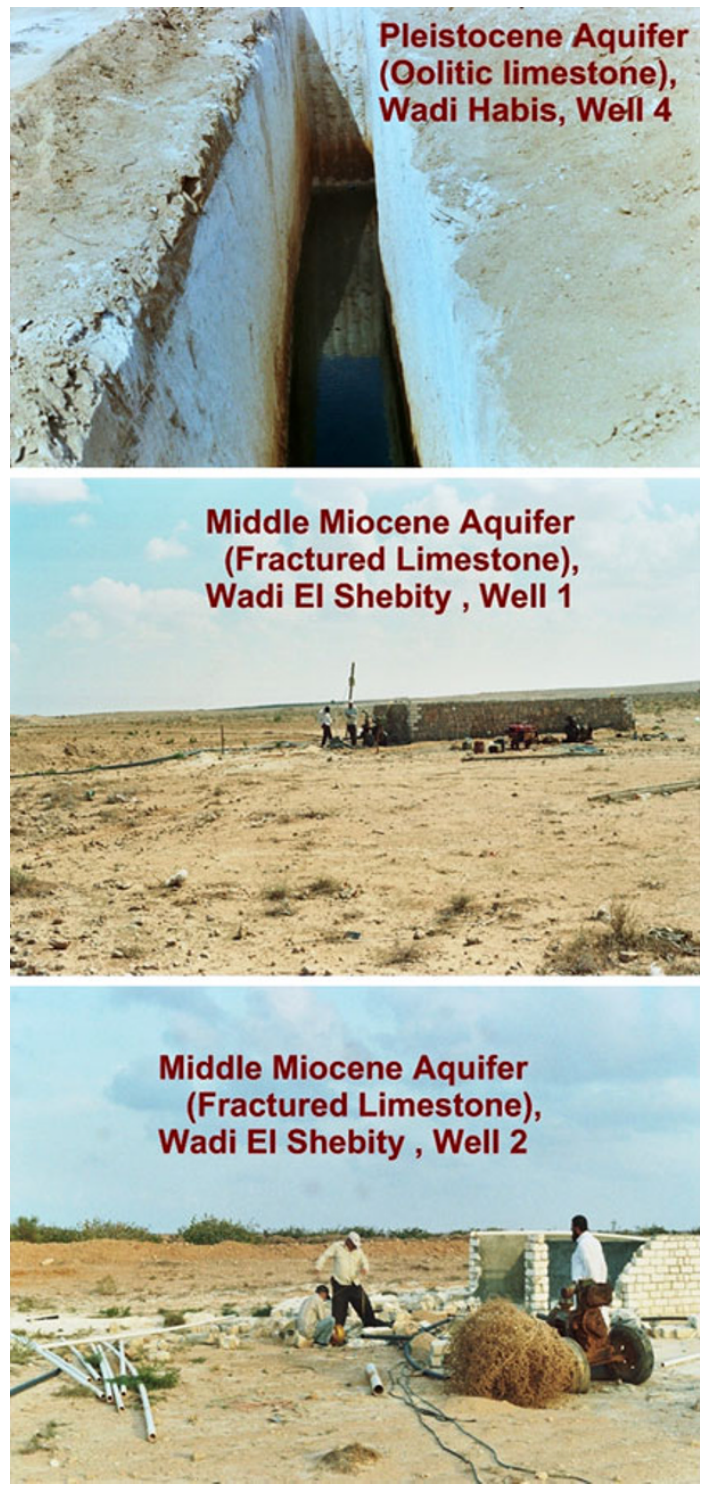

Fig. 10 Field photographs show the wells of the studied aquifers

water harvesting techniques has been developed for growing crops or for rehabilitation and development of rangelands, where rainfall is inadequate for rain fed agriculture and irrigation water is lacking. An amount of surface runoff in the study area is collected by means of stony dams built across drainage basins, and man-made underground storage cisterns or galleries, while the remainder of the surface runoff is flowing into the sea. In the present study and during the field investigations, the current water harvesting activities are recorded (Fig. 8).

From the above-mentioned discussion, it has to bear in mind that most of the surface runoff is running in the ephemeral drainage lines towards the coastal plain or to the sea. It is recommended with further constructions of the cisterns and reservoirs as a future plan to irrigate new lands and to maximize the agricultural development in the area. Such technique of water conservation is very suitable for the local inhabitants to keep the sort of settlement in the area of study. Therefore, in the present study, we prepared some recommendations for the future surface water development in the form of suggested sites for cisterns, reservoirs, and dams to conserve additional quantities of surface water rather than waste it in the sea. These recommendations are based on the field investigations, topographic maps (scale 1:25000), and flow direction maps (Fig. 9) as well as the geologic and geomorphologic settings. Therefore, the best sites for cisterns, dams, and reservoirs are chosen and illustrated in Fig. (11).

\section{Groundwater}

The water points in the study area are so limited (only four wells), where the groundwater occurs in Pleistocene and Middle Miocene aquifers (Figs. 8 and 10). Their hydrogeological characteristics are given:

\section{Pleistocene aquifer}

The Pleistocene aquifer characterized by wide distribution along the northwestern coast of Egypt and is composed of highly porous white oolitic limestone of the coastal and internal ridges and represented by one hand-dug well in the Piedmont plain of Wadi Habis (well no. 4). The groundwater was recorded at depth $4.5 \mathrm{~m}$ from ground surface and total depth of $6.1 \mathrm{~m}$ with salinity about $4181 \mathrm{ppm}$, (Table 3). The groundwater recharged from the local rainfall and flood. The high salinity of the groundwater is attributed to the dissolution of marine sediments. The cationic sequences revealed that sodium is the dominant cation followed by magnesium and calcium $\left(\mathrm{Na}^{+}>\right.$ $\left.\mathrm{Mg}^{++}>\mathrm{Ca}^{++}\right)$. The anionic sequences revealed that the chloride is the dominant anion followed by sulfate and bicarbonate $\left(\mathrm{Cl}^{-}>\mathrm{SO}_{4}{ }^{-}>\mathrm{HCO}_{3}{ }^{-}\right)$; therefore, the groundwater type is $\mathrm{Na}-\mathrm{Cl}$. The hypothetical salts combinations are $\mathrm{NaCl}, \mathrm{MgSO}_{4}, \mathrm{Ca}\left(\mathrm{HCO}_{3}\right)_{2}, \mathrm{Mg}\left(\mathrm{HCO}_{3}\right)_{2}$, and $\mathrm{Na}_{2} \mathrm{SO}_{4}$. The hydrochemical coefficients are used for detecting the origin of groundwater and previous hydrochemical processes affecting the water quality. The hydrochemical coefficients $\mathrm{rNa} / \mathrm{rCl}, \mathrm{rSO}_{4} / \mathrm{rCl}$, and $\mathrm{rCa} / \mathrm{rMg}$ are the most indicatives (Table 3). The value of $\mathrm{rNa} / \mathrm{rCl}$ exceeds unity reflecting the meteoric water origin. $\mathrm{rSO}_{4} / \mathrm{rCl}$ and $\mathrm{rCa} / \mathrm{rMg}$ show low values reflecting dissolution processes of marine sediments.

\section{Middle Miocene aquifer}

The Middle Miocene aquifer is composed of Fossiliferous limestone, chalky limestone, marl, and gray clay intercalations (Marmarica formation) and represented by one 


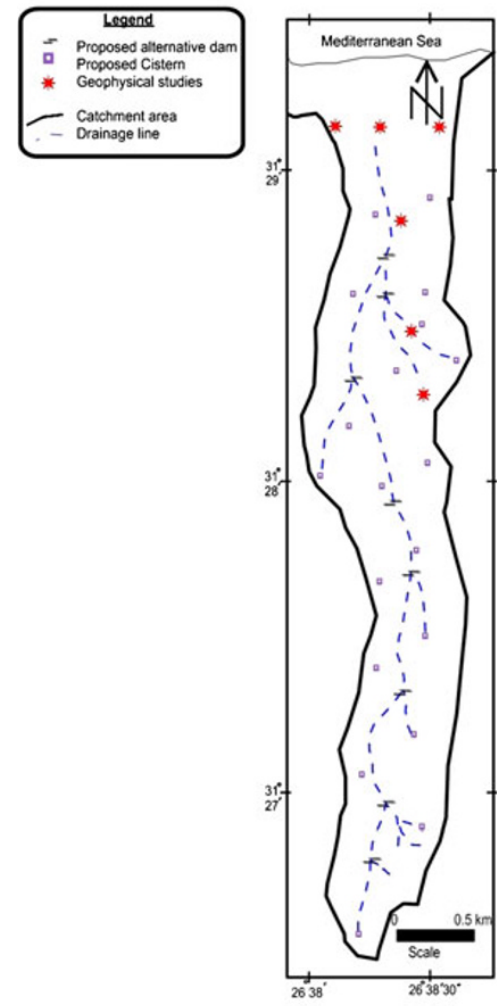

Wadi Shebity

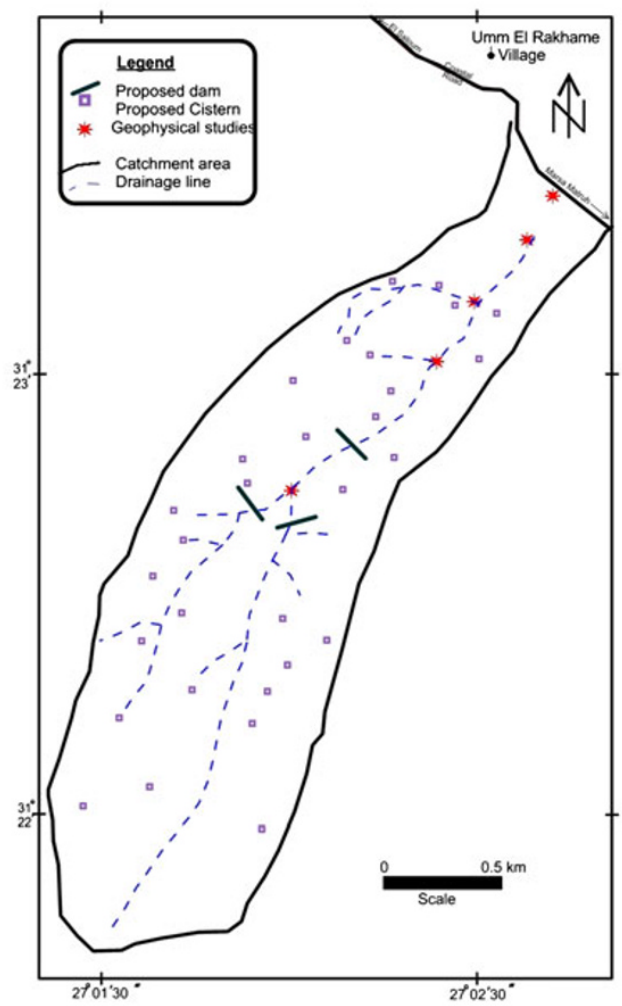

Wadi Habis

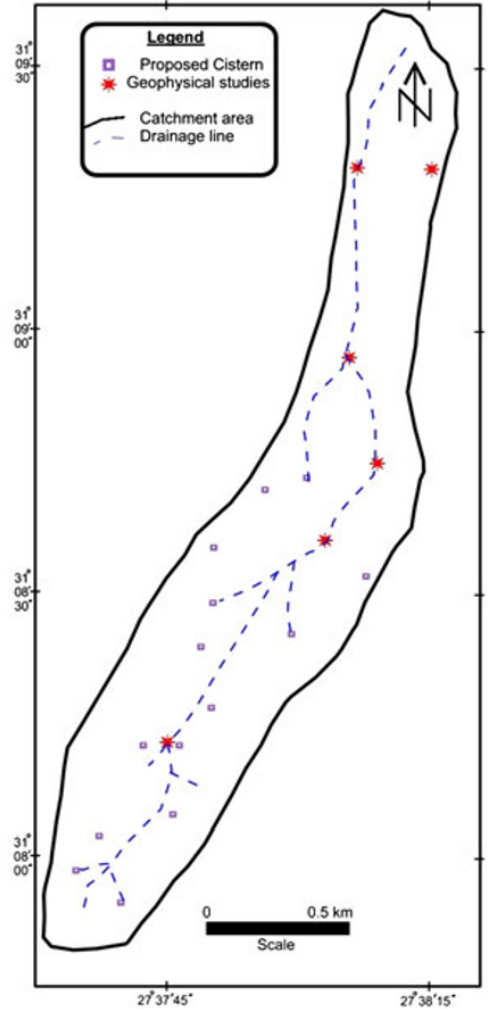

Wadi Hashim

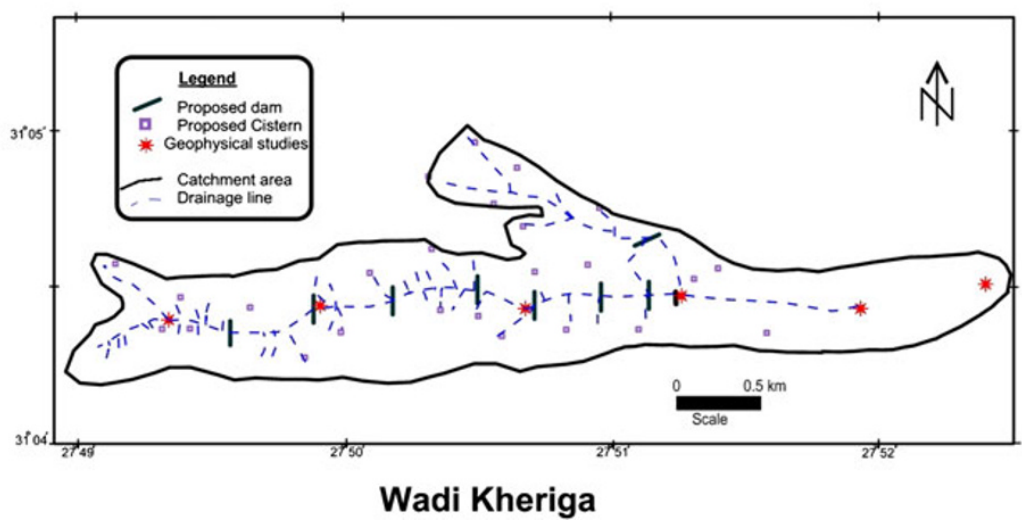

Fig. 11 Recommendation maps for water resources development in the studied basins

hand-dug well in the Piedmont plain of Wadi Habis (well no. 3) and two drilled wells in the Piedmont plain of Wadi Shebity (Figs. 1 and 2). The aquifer is highly fractured and cavernous where its groundwater recorded at depths $8.4 \mathrm{~m}$ (well no. 3), 35 (well no. 1), and 32.35 (well no. 2) from ground surface with salinities about 3,317 ppm (well no. 3), 4,337 ppm (well no. 1), and 4,249 ppm (well no. 2) (Table). The groundwater is recharged from the local rainfall and flood. The high salinity of the groundwater is attributed to the dissolution of marine sediments. The cationic sequences revealed that sodium is the dominant cation followed by magnesium and calcium $\left(\mathrm{Na}^{+}>\right.$ $\left.\mathrm{Mg}^{++}>\mathrm{Ca}^{++}\right)$. The anionic sequences revealed that the chloride is the dominant followed by sulfate and bicarbonate $\left(\mathrm{Cl}^{-}>\mathrm{SO}_{4}{ }^{-}>\mathrm{HCO}_{3}{ }^{-}\right)$, the groundwater type is $\mathrm{Na}-\mathrm{Cl}$.

The hypothetical salts combinations are:

$\mathrm{NaCl}, \mathrm{MgSO}_{4}, \mathrm{Ca}\left(\mathrm{HCO}_{3}\right)_{2}, \mathrm{Mg}\left(\mathrm{HCO}_{3}\right)_{2}$ and $\mathrm{MgCl}_{2}$ (wellno.1)

$\mathrm{NaCl}, \mathrm{MgSO}_{4}, \mathrm{Ca}\left(\mathrm{HCO}_{3}\right)_{2}, \mathrm{MgCl}_{2}$ and $\mathrm{Mg}\left(\mathrm{HCO}_{3}\right)_{2}$

(wellno.2) 
Table 3 The hydrochemical data of the groundwater samples in the study area

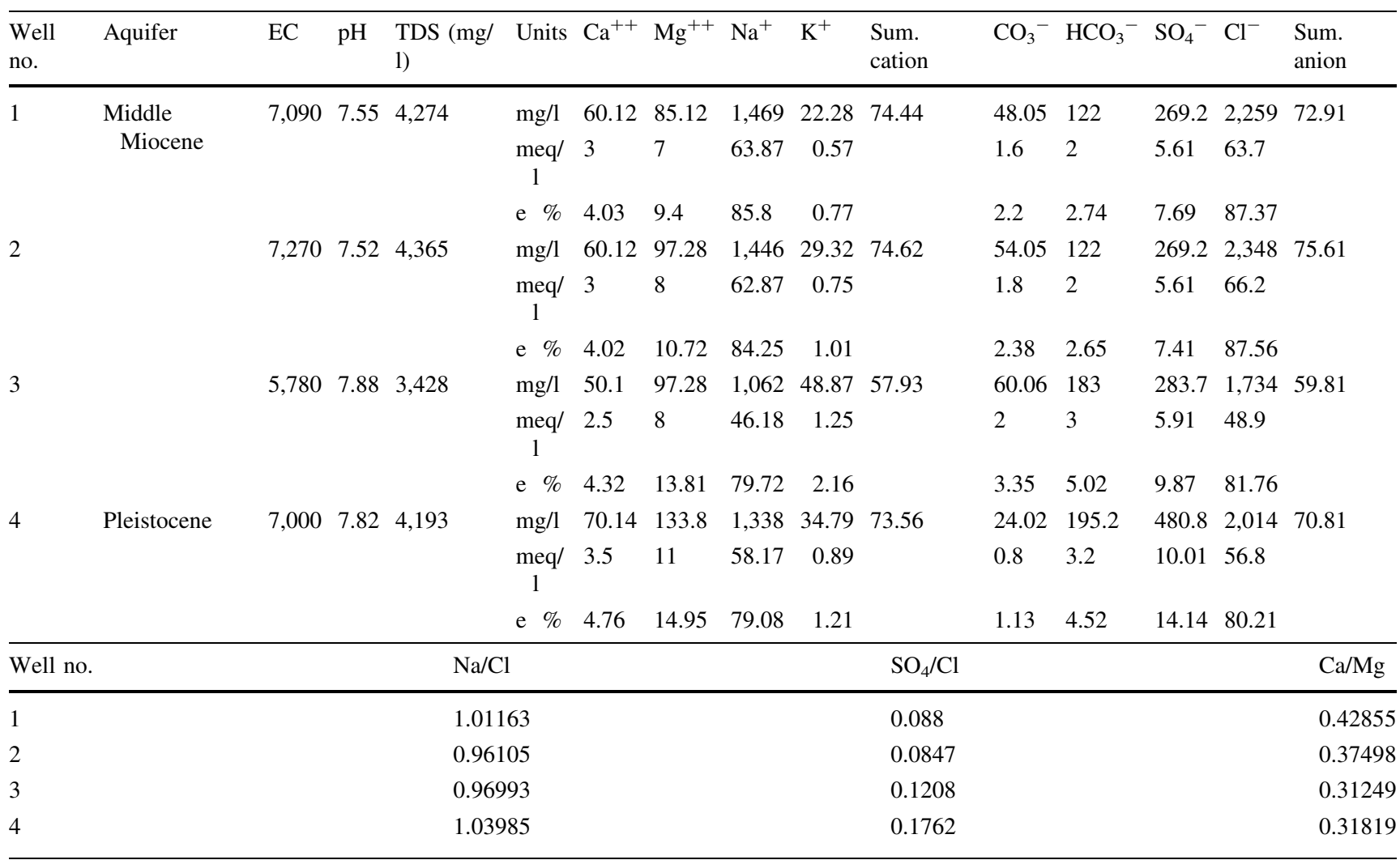

$\mathrm{NaCl}, \mathrm{MgSO}_{4}, \mathrm{Ca}\left(\mathrm{HCO}_{3}\right)_{2}, \mathrm{Mg}\left(\mathrm{HCO}_{3}\right)_{2}$ and $\mathrm{Na}_{2} \mathrm{SO}_{4}$

(wellno.3)

The hydrochemical coefficient $\mathrm{rNa} / \mathrm{rCl}$ exceeds unity and more than that of seawater (0.87) reflecting the meteoric water origin. $\mathrm{rSO}_{4} / \mathrm{rCl}$ and $\mathrm{rCa} / \mathrm{rMg}$ show low values reflecting dissolution processes of marine sediments.

\section{Evaluation of groundwater according to salinity}

All the groundwater samples are unsuitable for drinking and domestic uses (World Health Organization (WHO 2011), satisfactory for livestock and poultry (National Academy of Science 1972) and unsuitable for irrigation (U.S. Salinity laboratory Staff 1954).

From the above discussion, and based on the geologic and geomorphologic settings of the studied basins, it can be concluded that the Middle Miocene aquifer can be considered as a promising aquifer in the studied basins. This aquifer should be subjected to geophysical studies to evaluate its potentialities. Therefore, the present study reaches to the best sites, which have been chosen to carry out the geophysical studies (especially vertical electrical sounding) in the studied basins (Fig. 11). These sites were chosen according to some factors such as, the drainage network in the studied basins, the density and frequency of the fractures in the Middle Miocene limestone, the flow direction of the surface water, and the annual rainfall in the study area.

\section{Conclusions}

The northwestern coast of Egypt has an international interest due to its history and magnificent environment. Therefore, studies on development of water resources in such regions are considered of vital importance. The current research is an integration between some studies for water resources development; these studies include geomorphology, geology, and hydrogeology. The main objective of this paper is to monitor and record data about the current surface and groundwater as well as to have a systematic understanding of the water resources base in the area of study. The present research distinguished the water resources into the surface water and groundwater. In the study area, some of the water harvesting techniques has been developed for growing crops or for rehabilitation and development of rangelands, where rainfall is inadequate for rain fed agriculture and irrigation water is lacking. An 
amount of surface runoff in the study area is collected by means of stony dams built across the drainage basins, and man-made underground storage cisterns or galleries, while the remainder of the surface runoff is going into the sea. The groundwater recharge of annual precipitation is depending on climate, land use, soil type, geology and many other factors of annual precipitation that results in groundwater recharge. The groundwater aquifers in the study area are subdivided according to its occurrences into two aquifers; the Pleistocene oolitic limestone aquifer and the Middle Miocene fissured limestone aquifer. The present study reaches to some recommendations related to the development of surface and groundwater in the studied basins, these recommendations were illustrated in Fig. 11.

Open Access This article is distributed under the terms of the Creative Commons Attribution License which permits any use, distribution, and reproduction in any medium, provided the original author(s) and the source are credited.

\section{References}

Conoco (1986) Geological map of Egypt, scale 1:500,000 GPC, sheets No. NH35NE

El Bastawesy MA, Ali RR, Nasr AH (2008) The use of remote sensing and GIS for catchments delineation in Northwester Coast of Egypt: an assessment of water resources and soil potential. Egypt J Remote Sens Space Sci 11:3-16

El Maghraby M (1997) Geophysical, hydrogeological and remote sensing studies on the effect of sea level fluctuation on the groundwater reservoir between Alexanandria and El Daba'a, Egypt, Ph.D. Thesis, Fac Sci Alex Univ, p 357

El Shamy I (1968) The geology of soil and water resources in El Daba'a area. M. Sc. Thesis, Fac Sci Cairo Univ, p 112

El Shazly M, Abdel Hady A, El Ghawaby A, El Kassas A (1975) Geologic interpretation of landsat satellite images for west Nile Delta area, Egypt, Remote Sens. Res. Proj. Acad. Sci. Res. Techn. Pap., p 38

El-Raey M (1998) Framework of integrated coastal area management of the Fuka-Matrouh area, Egypt, PAP/RAC-37

El-Raey M, Dewidar KR, El-Hattab M (1999) Adaptation to the impacts of sea level rise in Egypt. Mitig Adapt Strateg Glob Change 4:343-361

El-Sharabi ES (2000) Hydrogeological, geomorphological and geoenvironmental implications for future sustainable development of the northwestern coastal zone of Egypt. Ph.D. Thesis, Mansoura University, p 346

Ezzat M (1976) Groundwater resources of North Western Coastal Zone. Part 1, Ministry of irrigation, Cairo, Egypt
FAO (1970) Pre-investment survey of the northwestern coastal region: physical conditions and water resources. Technical report 2 (ESE: SF/UAR 49), p 140

Guindy Kh (1989) Hydrogeology of the coastal zone between El Ameriya and El Hammam. Ph.D thesis, Fac. Sci., Ain Shams Univ., Cairo, p 151

Hammad FA (1966) The geology of water supplies in Ras El Hekma area. M. Sc. Thesis, Fac. Sci. Cairo Univ., p 109

Hammad FA (1972) The geology of soils and water resources in the area between Ras El Hekma and Ras El Rum (Western Mediterranean Littoral Zone, Egypt). Ph.D. Thesis, Fac. Sci. Cairo Univ., p 162

Hilmy M, El Shazly M, Korany E (1978) Lithostratigraphy and petrology of the Miocene and post-Miocene sediments in Burg El Arab-El Daba'a area. Desert Inst Bull A R E 28(1):1-24

Klaric Z, Komilis P, Dragicevic M, Berlengi G, Surucu F, Raey M, Abdrabo M, Nasr S, El-Bastawissi E, Hattab M, Shalaby A, Mohammed W (1999) Carrying capacity assessment for tourism development of the coastal area management programme (CAMP) Fuka-Matrouh, Egypt. PAP/RAC, Split, Croatia (PAP/RAC. pp vi + 74. ENG). Available at: http://www.paphe coastcentre.org/pdfs/CCA\%20for\%20Tourism\%20Development. pdf

Misak R (1974) Geomorphology and geology of the area between El Daba'a and Ras El Hekma, Western Mediterranean coastal zone, Egypt. M. Sc. Thesis, Fac. Sci. Ain Shamas Univ., p 144

Mudallal UH (1990) Hydrogeological studies of areas in the North Western coastal zone and Siwa. Project EGY/87/010, FAO, Rome, p 133

NARSS (2005) National authority for remote sensing \& space sciences, environmental evaluation of land resources in the Northwestern Coast of Egypt, using space data and land information systems, Phase II: Area from Sedi Abd EL-Rahman to Marsa El-Assi Fainal report, No. 101/SR/ENV/04-0, June 2005. NARSS, Cairo, Egypt

National Academy of Science and National Academy of Engineering (1972) Water quality criteria, Protection Agency, Washington, p 594

Raslan SM (1995) Geomorphological and hydrogeological studies on some localities along the Northwestern Coast of Egypt, M. Sc. Thesis, Faculty of Science, Menoufia University, p 172

Sewidan AS (1978) Water Budget analysis for the northwestern coastal zone. Ph.D Thesis, Fac. Sci. Cairo Univ., p 179

Taha A (1973) Geology of water supplies of Matruh-Barrani area, Northwestern Mediterranean coastal zone, Egypt. Ph.D. Thesis, Fac Sci, Alex Univ, p 253

U.S. Salinity Laboratory Staff (1954) Diagonsis and improvement saline and alkali soil: agric, handbook, 60, Washington, pp 1-60

Ward RC (1975) Principles of Hydrology, McGraw-Hill, UK pp 256-262

World Health Organization (WHO) (2011) The guidelines for drinking-water quality 4th ed. ISBN $978 \quad 92 \quad 4 \quad 154815 \quad 1$, Available on: http://www.who.int, p 564 